\title{
Absorption and Effect of Azaspiracid-1 Over the Human Intestinal Barrier
}

\author{
Paula Abala M. Carmen Louzao ${ }^{a} \quad$ María Fraga $^{a} \quad$ Natalia Vilariño ${ }^{a}$ Sara Ferreiro ${ }^{a}$ \\ Mercedes R. Vieytes ${ }^{b} \quad$ Luis M. Botana ${ }^{a}$ \\ aDepartamento de Farmacología, Facultad de Veterinaria, Universidad de Santiago de Compostela, \\ Lugo, 'Departamento de Fisiología, Facultad de Veterinaria, Universidad de Santiago de Compostela, \\ Lugo, Spain
}

\section{Key Words}

Azaspiracid • Caco-2 cells $\bullet$ Intestinal permeability • Trans-epithelial electric resistance $\bullet$ Toxin absorption.

\begin{abstract}
Background: Azaspiracids (AZAs) are marine biotoxins produced by the dinoflagellates genera Azadinium and Amphidoma. These toxins cause azaspiracid poisoning (AZP), characterized by severe gastrointestinal illness in humans after the consumption of bivalve molluscs contaminated with AZAs. The main aim of the present study was to examine the consequences of human exposure to AZA1 by the study of absorption and effects of the toxin on Caco-2 cells, a reliable model of the human intestine. Methods: The ability of AZA1 to cross the human intestinal epithelium has been evaluated by the Caco-2 transepithelial permeability assay. The toxin has been detected and quantified using a microsphere-based immunoassay. Cell alterations and ultrastructural effects has been observed with confocal and transmission electron microscopy Results: AZA1 was absorbed by Caco-2 cells in a dosedependent way without affecting cell viability. However, modifications on occludin distribution detected by confocal microscopy imaging indicated a possible monolayer integrity disruption. Nevertheless, transmission electron microscopy imaging revealed ultrastructural damages at the nucleus and mitochondria with autophagosomes in the cytoplasm, however, tight junctions and microvilli remained unaffected. Conclusion: After the ingestion of molluscs with the AZA1, the toxin will be transported through the human intestinal barrier to blood causing damage on epithelial cells.
\end{abstract}

\section{Introduction}

Azaspiracids (AZAs) are a group of lipophilic marine biotoxins of microalgal origin produced by the genera Azadinium and Amphidoma although not all species are toxic [1,2]. Since the discovery of AZAs, more than 30 analogues were identified in phytoplankton [3]

Departamento de Farmacología, Facultad de Veterinaria

Universidad de Santiago de Compostela, Lugo, (Spain)

Tel. +34 982822 233, E-Mail luis.botana@usc.es/mcarmen.louzao@usc.es 
and shellfish. AZAs can be accumulated in high concentrations in bivalves due to their filterfeeding activity and reach humans through the food web. The ingestion of contaminated shellfish leads to the syndrome known as Azaspiracid poisoning (AZP) [4], manifested through gastrointestinal symptoms such as diarrhea, nausea, vomiting and stomach cramps in humans. Due to the similarity of these acute symptoms AZP was initially considered as a diarrhetic shellfish poisoning (DSP), but later AZAs were demonstrated not to share DSPs mechanism of toxicity [5].

Toxicological studies have indicated that oral administration of AZAs to mice induces dose and time-dependent gastrointestinal symptoms, in addition to widespread organ damage $[5,6]$. Those studies revealed fluid accumulation in the small intestine and necrosis of lamina propia leading to erosion, also fatty acid droplets in liver, reduction of lymphocytes in the spleen and thymus and increased prevalence of lung tumor [6]. Further in vivo studies linked AZA exposure to neurotoxicity and cardiotoxicity. Thereby, mice that received AZAs by intraperitoneal (i.p.) injection showed neurological symptoms, characterized by slow and progressive paralysis, respiratory difficulties and spasms [7]. Furthermore, hearth arrythmogenicity and subacute cardiovascular toxicity have been also described for AZAs $[8,9]$ that should be considered to evaluate the cardiovascular risk of these toxins.

In spite of that, AZAs mechanism of action is not fully understood. In vitro studies have indicated that AZAs produce a range of cellular and molecular effects. AZAs elevate caspase activity [10], cause disarrangement and reduction of cellular F-actin and impaire cell-cell adhesion in several mammalian cells types [11,12]. Azaspiracid 1 (AZA1) prevents endocytosis [13] and causes a pronounced and temporary depletion of ATP, which may be related to the altered expression of proteins involved in several cellular functions. In addition, AZAs increase cytosolic calcium levels and cellular concentrations of cAMP [11]. Recently, AZA1 was proposed as a low/moderate hERG potassium channels blocker [14]. AZAs produce trafficking alterations on hERG channel [15] that support in vivo subacute toxicity [9]. On the other hand, AZAs inhibit neuronal ion flux and bioelectrical activity that was related to neurotoxicity [10]. Even in some studies glutaric acid and azaspiracid inhibited the activity of the sodium channel by over $50 \%$ [16].

Currently the presence of AZAs is widespread in bivalves from different coastal regions of Europe [17] having a significant economic and health impact. Most of AZA analogues have been suggested to be shellfish biotransformation products, even though AZA1 and AZA2 are the parent compounds [18]. Therefore only the content of AZA1-3 is under regulation by food safety authorities [19]. The EU establishes a toxin limit of $160 \mu \mathrm{g}$ AZA-1 equivalents $/ \mathrm{kg}$ shellfish meat in products destined for the market [20].

The symptoms induced by AZAs in vivo and the widespread occurrence of the toxins demand elucidation of its biological targets and effects in humans to protect shellfish consumers, minimize the risk and combat the possible diseases.

In the present work, we assess the intestinal absorption and potential effect of AZAs over the human intestinal barrier. Various methods can be used for the determination of the toxin permeability including in vivo intestinal perfusion studies in animals, in vitro permeation studies using excised human or animal intestinal tissues and in vitro permeation studies across a monolayer of cultured epithelial cells [21].

The study of the AZAs intestinal absorption was performed by using an in vitro cellbased transwell model with differentiated Caco-2 cells and an accurate well-characterized AZA1 standard. The human Caco-2 cell line [22] derived from a human colon carcinoma and differentiates in culture to cells similar to small intestinal enterocytes [23]. On transwell inserts the differentiated Caco- 2 cells form a polarized epithelial monolayer where the apical compartment represents the "luminal side" of the small intestine and the basolateral side the "blood side". This system serves as a useful model for the gastrointestinal barrier [24, 25]. Therefore, in this model we evaluated the passage of AZA1 through the cell monolayer and cell alterations. 


\section{Cellular Physiology Cell Physiol Biochem 2017;43:136-146 \begin{tabular}{l|l|l} 
and Biochemistry Published onlIne: August 28, 2017 & $\begin{array}{l}\text { (c) } 2017 \text { The Author(s). Published by S. Karger AG, Basel } \\
\text { www.karger.com/cpb }\end{array}$
\end{tabular}}

Abal et al.: Absorption of Azaspiracid-1

\section{Materials and Methods}

\section{Reagents}

Azaspiracid-1 (AZA1) with a purity $\geq 98 \%$ is a certified reference material (CRM) supplied by Laboratorio CIFGA S.A. (Lugo, Spain). AlamarBlue $₫$, anti-occludin mouse monoclonal antibody labeled with AlexaFluor 488, Trypsin-EDTA (1X) $0.25 \%$ and Non-essential aminoacids (100X) were purchased from Invitrogen (Camarillo, CA, USA). Trypan blue solution 0.4\%, penicillin-streptomycin solution, Triton X-100, bovine serum albumina (BSA) were from Sigma-Aldrich (St. Louis, MO, USA). Minimum essential medium (MEM) and fetal bovine serum (FBS) were purchased from Biowest (Nuaillé, France). Other reagents used were purchased from Sigma-Aldrich (Madrid, Spain) and Panreac (Barcelona, Spain). The cell fixation solution for TEM was $2.5 \%$ glutaraldehyde, $0.1 \mathrm{M} \mathrm{CaCl}_{2}$ and $0.2 \mathrm{M}$ sodium cacodylate trihydrate, this last was used as a buffer.

Cell line culture

The Caco-2 cell line is derived from a human colon adenocarcinoma and it was obtained from the American Type Culture Collection (ATCC, Manasas, VA, Item №: HTB-37). These cells are able to spontaneously differentiate to enterocytes, expressing the brush border enzyme activities and representing a reliable model of the human intestine. Cells were routinely cultured as previously described [25]. Briefly, the cells were grown in $75 \mathrm{~cm}^{2}$ tissue flask, incubated at $37^{\circ} \mathrm{C}$ in a humidified atmosphere containing $5 \%$ $\mathrm{CO}_{2}$. The culture medium was renewed every 2-3 days. The cells were subcultured once per week. The cell viability was always higher than 95\%, evaluated with Trypan Blue solution.

Cytotoxicity assay

Cellular viability was assessed using AlamarBlue assay as previously described [26].

Caco-2 cells were seeded in sterile 96-well culture plates (Corning, NY, USA) at 25000 cells/mL and cultured until differentiation for 21 days renewing the culture medium every 2-3 days. Then, cells were treated with different concentrations of AZA1: 0.1, 0.5, 1, 5, 10, 50, 100 and $500 \mathrm{nM}$ in the presence of AlamarBlue ${ }^{\circledR}$. Fluorescence was measured at 6, 8, 10, 12, 24, 48 and 72 hours of continuous exposure using a FL600 Microplate Fluorescence Reader from BioTek (Winooski, VT, USA), at an excitation wavelength of $530 \mathrm{~nm}$ and emission wavelength of $590 \mathrm{~nm}$. The mean of the fluorescence data was calculated for each treatment and controls. Results are expressed as the percentage of the fluorescence of treated cells versus controls (control cells were considered as having 100\% viability).

\section{Trans-epithelial Electric Resistance measurement}

The Caco-2 monolayer integrity was assessed thought measurement of the trans-epithelial electric resistance (TEER) with Millicell $@$ ERS Multimeter from Millipore Corporation (Billerica, MA, USA) as previously described by Espiña et al. (2011) [25]. Caco-2 cells were cultured at a density of 120000 cells/ $\mathrm{mL}$ on sterile Millicell hanging culture inserts of $0.4 \mu \mathrm{m}$ pore size PET membrane, which were individually placed on a Falcon 12-well. The content of the insert represent the apical side of the intestinal cell monolayer, towards which microvilli were oriented and the well the basolateral side. Once cells had spent 21 days seeded in the inserts, TEER was measured after changing the medium. Measurements from blank inserts were subtracted to calculate resistance of the cell monolayer with the following formula:

Resistance $(\Omega)=R_{S}-R_{B}$

Where $R_{S}$ is the resistance of Caco- 2 monolayer samples, $R_{B}$ is the resistance of the membrane insert.

TEER values were presented as Resistence of a unit area with the next formula:

$\operatorname{TEER}\left(\Omega \mathrm{cm}^{2}\right)=$ Resistance $\times 1.1$

$1.1\left(\mathrm{~cm}^{2}\right)$ is the effective surface area of the filter membrane. Only Caco-2 monolayers with initial TEER values higher than $300 \Omega \mathrm{cm}^{2}$, which indicates that the cell monolayer is intact and suitable for drug permeability assays, were used. The TEER was measured at the beginning of the experiment and after 1, 2, $3,6,12$ and 24 hours of toxin treatment. Changes in TEER during experimental conditions were calculated as a ratio between toxin treated samples and control samples (TEER RATIO).

Permeability assays in Caco-2 cells

The permeability assay was carried out as previously described by Fernandez et al. (2014) [26]. The transport experiments were performed in the insert/well configuration with differentiated Caco-2 monolayer over the PET semipermeable membrane. The transport experiment was started by positioning 


\section{Cellular Physiology Cell Physiol Biochem 2017;43:136-146 \begin{tabular}{l|l|l} 
DOI: 10.1159/000480331 28, 2017 & $\begin{array}{l}\text { O 2017 The Author(s). Published by S. Karger AG, Basel } \\
\text { www.karger.com/cpb }\end{array}$ \\
and Biochemistry Published online: August 28,
\end{tabular}}

Abal et al.: Absorption of Azaspiracid-1

the inserts with the differentiated Caco-2 cells into wells containing $1.5 \mathrm{~mL}$ of fresh supplemented EMEM without FBS. Then a volume of $0.5 \mathrm{~mL}$ supplemented EMEM without FBS containing the toxin $(10$ or $100 \mathrm{nM}$ AZA1) or vehicle (methanol; control) was added to the cell monolayers that were incubated at $37^{\circ} \mathrm{C}$ in $95 \%$ relative humidity with $5 \% \mathrm{CO}_{2}$. After completion on AZA1 treatments $(3,6,12$ and 24 hours), the medium of both insert and well compartments was collected for toxin quantification purposes.

\section{Microsphere-based immunoassay for AZA1 detection}

AZA1 was quantified by the microsphere-based immunoassay as previously described in Fraga et al. (2014) [27]. This is an inhibition immunoassay for the detection of AZAs using the competition between AZA1 attached to the microspheres and free AZA1 in the samples for binding to the monoclonal anti-AZA antibody (mAb 8F4). The specific antibody bound to the surface of the AZA1 microspheres was quantified using a Phycoerythrin-labeled antimouse antibody (PE-Ab). PE-fluorescence intensity bound to the AZA1microspheres was measured with a Luminex $200^{\mathrm{TM}}$ analyzer (LuminexCorp, Austin, TX).

\section{Confocal microscopy imaging}

Occludin is an integral transmembrane protein of tight junctions. Alexa Fluor ${ }^{\circledR}$ 488-labeled antioccludin mouse monoclonal antibody from Invitrogen (Camarillo, CA, USA) was used to visualize occludin, as previously described [26]. Briefly, cells with an initial concentration of 60000 cells $/ \mathrm{mL}$ were seeded on rounded crystal coverslips of $22 \mathrm{~mm}$ of diameter. After 21 days, differentiated Caco- 2 monolayers were treated with AZA1, vehicle or Triton-X 100 (as positive control of cellular death). After $24 \mathrm{~h}$ treatments, the cells were fixed and incubated with the anti-occludin antibody. Each experimental condition was performed in duplicate. Confocal imaging was then carried out with a 40x oil immersion objective of a Nikon Eclipse TE2000-E inverted microscope attached to the C1 laser confocal system and EZ-C1 V3.60 software (Nikon Instruments Europe B.V., Amstelveen, Netherlands). An Argon laser was selected to excite the Alexa Fluor 488 conjugated antibody.

\section{Transmission Electron Microscopy imaging}

Ultrastructural cell analysis was performed by a double fixation protocol for transmission electronic microscopy (TEM). Cells were cultured at 60000 cells/mL for 21 days, until differentiation, on $25 \mathrm{~mm}$ round plastic sterile coverslips, placed inside Nunclon 8-well culture plates. Once differentiated, monolayers were treated with 10 and $100 \mathrm{nM}$ AZA1 or vehicle for 3, 6, 12 and 24 hours at $37^{\circ} \mathrm{C}$ and $5 \% \mathrm{CO}_{2}$. After that the medium was removed and cells were fixed by immersion in $2.5 \%$ of glutaraldehyde in $0.2 \mathrm{M}$ sodium cacodylate buffer containing $0.1 \mathrm{M} \mathrm{CaCl}_{2}$, for $30 \mathrm{~min}$ at $4^{\circ} \mathrm{C}$ under gentle agitation. Then, the fixative solution was removed and the cells were rinsed three times with $0.2 \mathrm{M}$ sodium cacodylate buffer. Postfixation was carried out with $1 \% \mathrm{OsO}_{4}$ in $0.2 \mathrm{M}$ sodium cacodylate buffer. This solution was removed prior to inclusion in warm $2 \%$ agarose to obtain samples in agarose cubes, that later were dehydrated in graded series of ethanol solutions and finally embebed in Epon 812 resin (Momentive Specialty Chemicals Inc., Houston TX, USA). Ultrathin sections of monolayers were obtained with an Ultracult R ultramicrotome from Leica Microsystems GmbH (Wetzlar, Germany) and sections were stained with uranyl acetate and lead citrate. Ultrastructural cell analysis was performed with a JEOL JEM-1011 Transmission Electron Microscope (Jeol Ltd, Tokyo, Japan).

\section{Statistical analysis}

The results were analyzed using Student's two-tailed t-test for paired data or one-way ANOVA complemented with a post-test for multiple values where appropriate. A confidence interval of $95 \%$ with $p$ $\leq 0.05$ was considered statistically significant.

\section{Results}

Effect of AZA1 on Caco-2 monolayers viability

The differentiated Caco- 2 monolayers were treated with different AZA1 concentrations $(0.1,0.5,1,5,10,50,100$ and $500 \mathrm{nM})$ for $6,8,10,12,24,48$ and $72 \mathrm{~h}$ to determine whether the toxin induces cytotoxic effects. Viability was assessed by the AlamarBlue assay as described 


\section{Cellular Physiology Cell Physiol Biochem 2017;43:136-146 and Biochemistry \begin{tabular}{c|c} 
DOI: 10.1159/000480331 28, & $\begin{array}{l}\text { O } 2017 \text { The Author(s). Published by S. Karger AG, Basel } \\
\text { wumwkarger.com/cpb }\end{array}$
\end{tabular}

Fig. 1. Viability of differenciated Caco-2 cells treated with AZA1. Caco-2 monolayers were incubated with different concentrations of AZA1 for $6,8,10,12,24,48$ and $72 \mathrm{~h}$ and viability was assessed using the AlamarBlue assay. Results (mean $\pm \mathrm{SEM}$ ) are expressed as \% viability versus control.
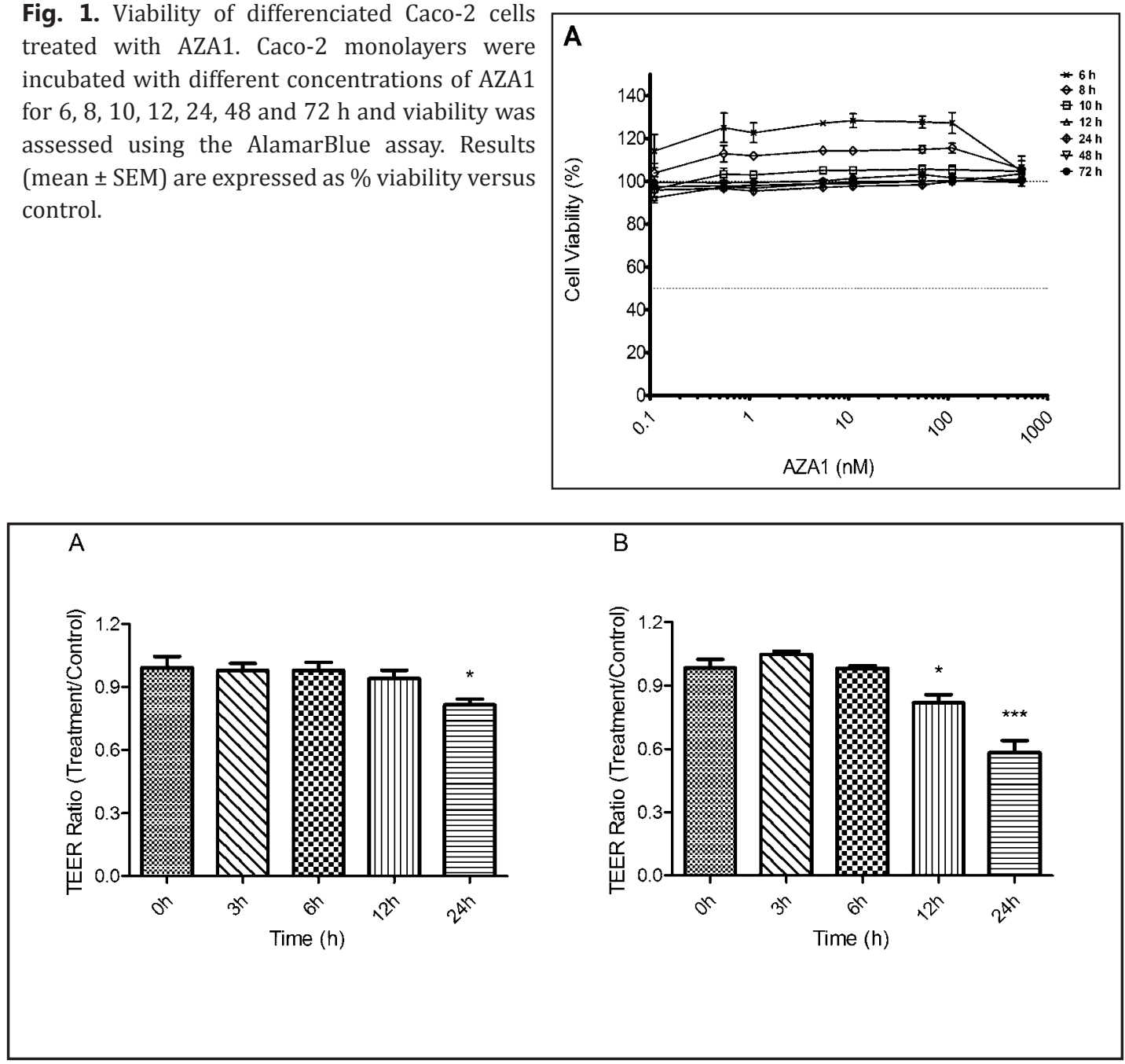

Fig. 2. Effect of AZA1 on trans-epithelial electric resistance of differentiated Caco- 2 monolayers. TEER values are presented as RATIO of $10 \mathrm{nM}$ (A) or $100 \mathrm{nM}$ (B) AZA1 treated to control monolayers. * Indicate statistically different $(\mathrm{P}<0.05)$ versus time $0 \mathrm{~h}$ and ${ }^{* * *}$ statistically different $(\mathrm{P}<0.001)$ versus time $0 \mathrm{~h}$.

in the Materials and Methods section. AZA1 did not significantly reduce the viability of Caco-2 cells at any concentration or incubation time tested. Data are presented in Fig. 1 as cell viability percentage versus control using mean values \pm SEM of three independent experiments performed in duplicate.

Effects of AZA1 on the trans-epithelial electrical resistance (TEER) of differentiated Caco-2 monolayers

Trans-epithelial electrical resistance (TEER) was measured to evaluate the changes that AZA1 induces in the Caco-2 monolayer integrity. Differentiated Caco-2 monolayers with initial TEER values higher than $300 \Omega \mathrm{cm}^{2}$ were incubated with 10 or $100 \mathrm{nM}$ AZA1 up to 24 h. TEER was measured before the addition of AZA1 and after 3, 6, 12 and $24 \mathrm{~h}$ incubation with the toxin. Results, belonging to four independent experiments, were presented in Fig. 2 as TEER Ratio between AZA1 treated and control monolayers. We observed a slightly TEER decrease in cells incubated with $10 \mathrm{nM}$ AZA1 for $12 \mathrm{~h}$ that was statistically significant after $24 \mathrm{~h}$ of incubation (18\%). The treatment with $100 \mathrm{nM}$ AZA1 triggered a significant decrease of the TEER value after $12 \mathrm{~h}$ of incubation that was more evident after $24 \mathrm{~h} \mathrm{(42 \% )}$ revealing a disturbance on the Caco-2 monolayer stability 


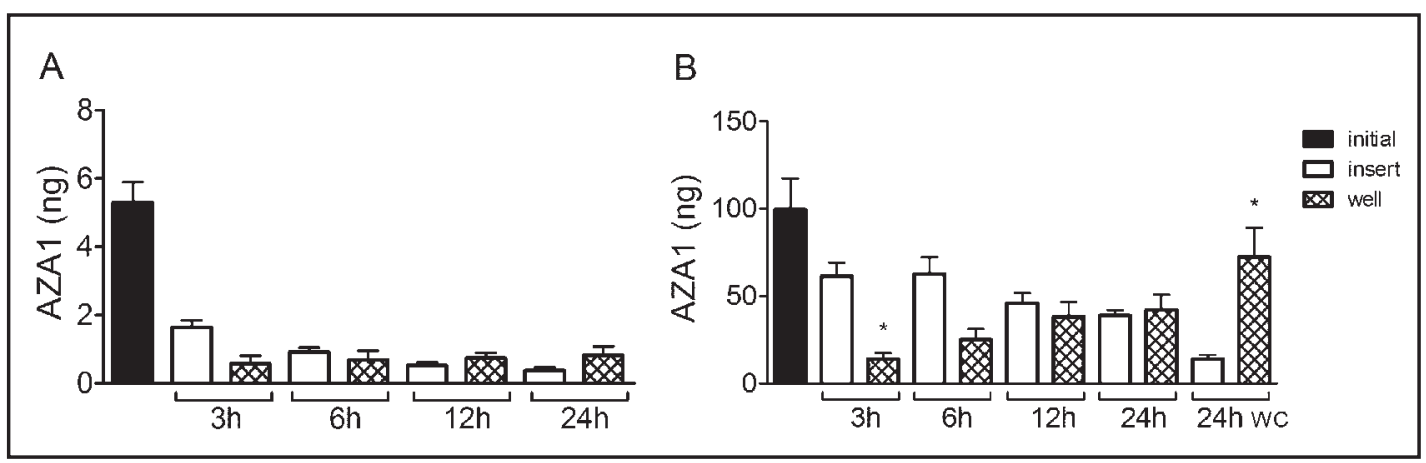

Fig. 3. Permeability of differentiated Caco-2 monolayers to AZA1. The toxin was quantified in samples taken from inserts with monolayers or wells. The cells were incubated with $10 \mathrm{nM}$ AZA1 (A) or $100 \mathrm{nM}$ AZA1 (B). The initial amount of toxin is represented by black bar. 24 WC represented the amount of AZA1 in samples taken from inserts and wells without Caco-2 monolayers. * Values of the well compartment (gridded bars) are statistically significant $(\mathrm{P}<0.05)$ compared to the paired values of inserts compartment represented by white bars. Values are the mean \pm SEM of three independent experiments.

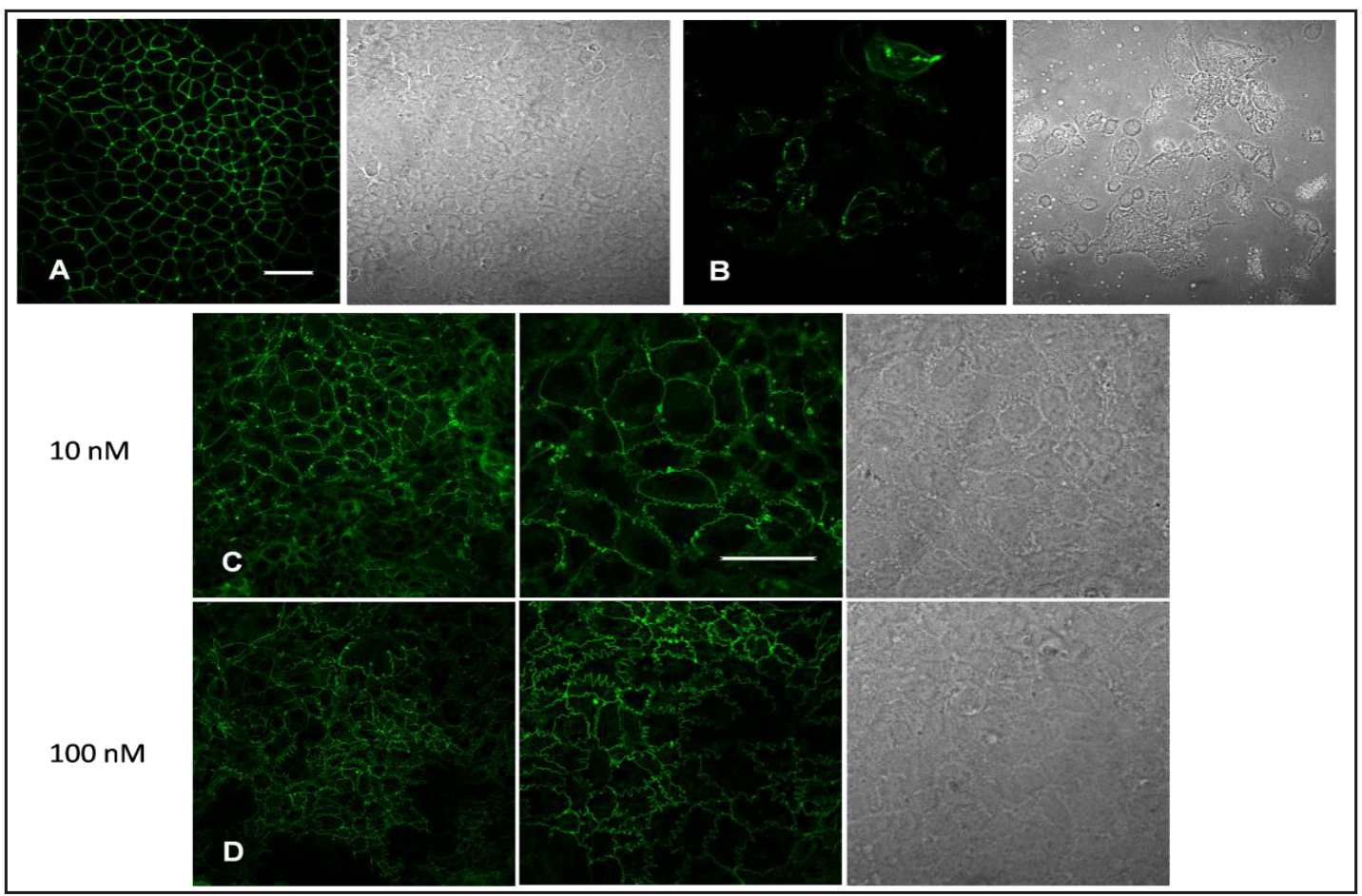

Fig. 4. Caco-2 monolayers labeled with anti-occludin mouse monoclonal antibody-Alexa® Fluor 488. (A) Control monolayers. Right: Alexa 488 fluorescence, left: birghtfield. (B) Caco-2 monolayers treated with 0,01\% Triton X-100 Right: Alexa 488 fluorescence, left: birghtfield. Caco-2 monolayers treated with $10 \mathrm{nM}$ AZA1 (C) or $100 \mathrm{nM}$ AZA1 (D) for $24 \mathrm{~h}$ with zoom and brigthfield images at right side of each one. The images are representative of six independent experiments in duplicate. Scale bar $=50 \mu \mathrm{m}$.

\section{Transepithelial Permeability of Caco-2 monolayers to AZA1}

To evaluate the transport of AZA1 through the cell monolayer we performed the transepithelial permeability assays. Caco-2 monolayers were incubated with $10 \mathrm{nM}$ and $100 \mathrm{nM}$ AZA1 for 3, 6, 12 and $24 \mathrm{~h}$. Fig. 3 shows the amount of AZA1 quantified in samples taken from the apical (insert) and basolateral (well) side as described in the Materials and Methods section. According to the results, AZA1 passed from the apical to the basolateral 


\section{Cellular Physiology

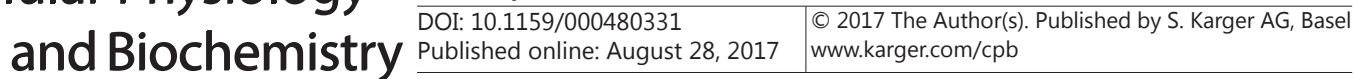

Fig. 5. Ultrastructural changes of differentiated Caco-2 monolayers incubated with 10 and $100 \mathrm{nM}$ AZA1 at different times observed by TEM imaging. (A) Control Caco-2 cells showing normal morphology. (B) Apical fraction of monolayer treated with $100 \mathrm{nM}$ AZA1 for 24 h with black mitochondria, microvilli and evident tight junctions between cells. (C-E) Autophagosomes (arrows) in a cells exposed to (C) $10 \mathrm{nM}$ AZA1 for $12 \mathrm{~h}$, (D) 100 nM AZA1 for $3 \mathrm{~h}$, (E),or $100 \mathrm{nM}$ AZA1 for $24 \mathrm{~h}$. (F) Altered nucleus after $12 \mathrm{~h}$ of treatment with $10 \mathrm{nM}$ AZA1. (G) Elongated dark mitochondria after $24 \mathrm{~h}$ incubation with $100 \mathrm{nM}$

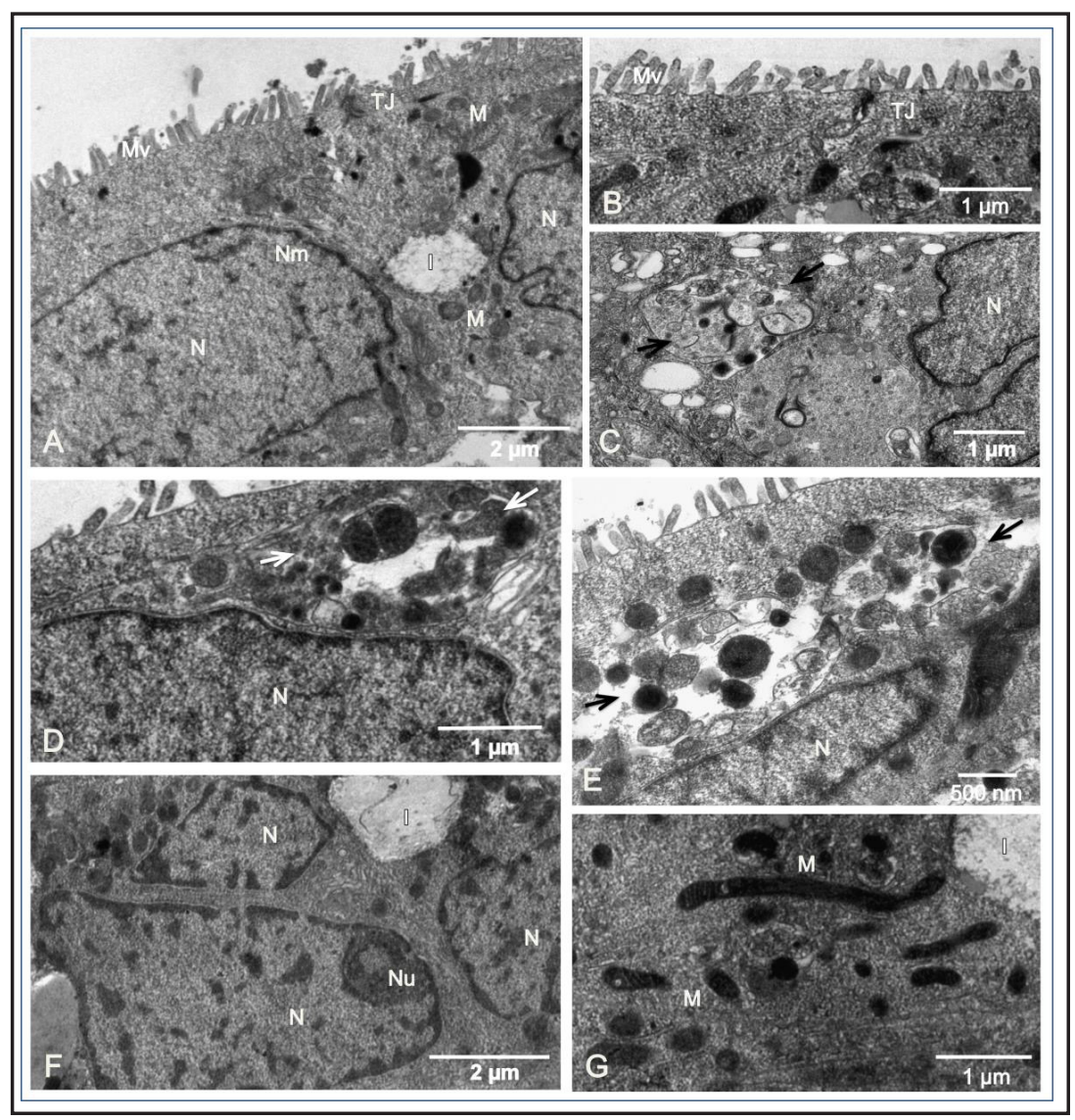
AZA1. The images are representative of three independent experiments in duplicate. Abbreviations of the cell structures: autophagosomes (A), amorphous cytoplasmic inclusions (I), mitochondria (M), microvilli (Mv), nucleus (N), nuclear membrane (Nm), nucleolus ( $\mathrm{Nu})$, tight junction (TJ).

side of the cells evidenced by a time-dependent decrease of toxin in the inserts and increase in the wells, particularly with the $100 \mathrm{nM} \mathrm{AZA1} \mathrm{(Fig.} \mathrm{3).}$

\section{Effect of AZA1 on Caco-2 occludin distribution}

TEER decrease in AZA1-treated Caco-2 cells indicates a possible alteration of the apical junction complexes in the monolayers. Therefore, occludin immunofluorescence labeling was performed to evaluate the integrity of TJ in Caco-2 cells treated with 10 and $100 \mathrm{nM}$ AZA1 for $24 \mathrm{~h}$. In control cells, occludin was distributed evenly at the cell border showing the monolayer integrity as a mesh form (Fig. 4A). However, occludin was redistributed in toxin treated samples, showing irregular cell borders with indentations between cells and loss of the netlike morphology at some points (Fig. 4D). In addition, in some cells occludin is relocalized from TJ to the cytosol (Fig. 4C). The redistribution and the granular appearance of occludin may suggest that TJ were disarranged by the effect of AZA1 in correlation with TEER reduction. However, detachment of cells from the substrate was not detected. Detachment of cells has been only induced by $0.01 \%$ Triton X-100 treatment (Fig. 4B) showing almost total monolayer disruption and lots of vesicles.

\section{Ultrastructural effect of AZA1 on Caco-2}

Transmission electron microscopy (TEM) imaging was performed to evaluate the AZA1-induced ultrastructural alterations in Caco-2 monolayers. Normal morphology of differentiated Caco-2 cell monolayers was seen in control samples (Fig. 5A), displaying 
cylindrical polarized morphology with microvilli on the apical side, and tight junctions between adjacent cells. Mitochondria were abundant and the nucleus presented welldefined nuclear membrane and nucleoli. The amorphous inclusions dispersed through out the cytoplasm are characteristic of this cell type (Fig. 5A, 5F). Caco-2 monolayers treated with $10 \mathrm{nM}$ and $100 \mathrm{nM}$ of AZA1 revealed tight junctions perfectly shaped and microvilli morphology similar to control samples (Fig. 5B). The presence of autophagosomes inside the cytoplasm are characteristic of AZA1-treated Caco-2 cells from the shortest incubation time of $3 \mathrm{~h}$ with $100 \mathrm{nM}$ AZA1 (Fig. 5D) and $12 \mathrm{~h}$ with $10 \mathrm{nM}$ (Fig. 5C). Their number of autophagosomes seems to increase with time of exposure (Fig. 5E). Damage of nuclei was also considerable. Nucleus presented lobed shapes for both concentrations (Fig. 5C, 5D) and even fragmentation after $24 \mathrm{~h}$ exposure to $10 \mathrm{nM}$ AZA1 (Fig. 5F) and at all incubation for $100 \mathrm{nM}$ AZA1. Furthermore, the heterochromatin was generally more condensed $24 \mathrm{~h}$ after treatment with $10 \mathrm{nM}$ (Fig. 5F). Mitochondrial injury was greatest in cells exposed to the highest AZA1 concentration at the longest exposure time assayed (Fig. 5E). In monolayers treated with $100 \mathrm{nM}$ for $24 \mathrm{~h}$, mitochondria were black with cristae clearly differentiated (Fig. 5B, 5G).

\section{Discussion}

People are exposed to AZAs by ingestion of contaminated seafood, therefore the goal of this work was to study the absorption and identify the effect of AZA1 on the human intestinal barrier using Caco-2 monolayers. This cell type differentiate spontaneously after 21 days of confluent culture, both functionally and structurally, to form a polarized epithelial cell monolayer composed by mature small intestine enterocytes with development of microvilli and TJ between adjacent cells [28]. The intestinal epithelial barrier is very important to understand the process of drug absorption and Caco-2 monolayers have been widely and successfully used for years as a model for human enterocytes [22]. Caco-2 monolayers have proved to be a valuable tool for predicting human in vivo intestinal permeability replacing or at least reducing in vivo studies with experimental animals [29]. Therefore, to measure intestinal permeability and absorption, the Caco- 2 cell model is considered to be the "industry gold standard" [30]

AZA1 is highly cytotoxic to some cell lines undergoing atypical apoptosis [31]. Related to this AZAs induced cytoskeleton disorganization linking the mechanism of action to apoptotic targets that responded with irreversible kinetics [12]. However, differentiated Caco-2 cells that are incubated with AZA1 did not suffer noticeable viability alterations, in accordance with previous data [32]. Nevertheless, when assays were performed with immature cells, cytotoxicity was evident which lysosomes may be responsible [33].

As previously described, differentiated Caco-2 cells on transwell inserts allows the study of transport mechanisms [24]. Our results revealed a time and dose-dependent permeation of AZA1 in Caco- 2 cells that indicates the passage of the marine toxin through the gut barrier. This passage correlated with the decrease of TEER that was previously described in AZA1 treatments even using low toxin concentrations [32]. In our hands, cell viability remains stable and the reduction of TEER values was related to a disruption of the barrier function due to a possible affectation of tight junctions.

Tight junctions (TJ) provide a physical and biochemical barrier to the passage of ions and small molecules $[28,34]$. The epithelial cells are linked together by those TJ that lay in the apical domain of epithelial cells and are mainly composed by transmembrane proteins such as claudins, the junctional adhesion molecule (JAM) proteins and occludin that connect to the actin cytoskeleton and microtube network. Occludin is an integral transmembrane protein that has been shown important for regulation of paracellular permeability of epithelial monolayers [34]. Therefore, TJ disruption modifies localization of proteins that shape it and increases permeability. The immunofluorescence technique for visualizing occludin showed that AZA1 caused non-uniform distribution of the occludin, evidenced 
as indentations between adjacent cells and internalization of the protein. These changes were detected without loss of cell viability reinforcing the possibility that AZA1 caused TJ alterations as was previously observed with other marine phycotoxins in intestinal cells [35]. However, some studies have shown that mice lacking occludin still maintain normal barrier function of intestinal epithelium and TJ did not appear to be affected morphologically [36]. Accordingly, TEM imaging of Caco-2 monolayers treated with AZA1 revealed that microvilli were not markedly altered and TJ maintained their structure. Therefore, the structure and functions of TJ in those cells cannot be explained by occludin alone further detailed studies of other tight junction proteins such as claudin, or JAMs are required to better understand the intestinal barrier.

Exposition of Caco-2 cells to $100 \mathrm{nM}$ AZA1 for $24 \mathrm{~h}$ induced the appearance of electrondense mitochondria. Changes in mitochondrial morphology during induction of autophagy have been already described in other intestinal cell types [37]. For instance mitochondrial elongation by fusion of mitochondria is a mechanism of organelle protection from being degraded by autophagy. Also long mitochondria are energetically more efficient as possess more cristae, increasing the activity of the ATP synthase [38]. The AZA1induced upregulation of energy metabolism was defined by Kellmann et al. (2009) [13] as a compensatory mechanism to maintain ATP levels. The nucleus was also affected by AZA1 appearing in TEM imaging as lobulated, fragmented, with condensed heterochromatin in most cases. All those ultrastructural changes could be related to the first stage of an apoptotic process which may suggest a transition between the two types of programmed cell death: apoptosis or autophagy. Additional experiments with a positive control for apoptosis [39] would be interesting to further corroborate the implication of the apoptotic process.

The process of autophagy triggers with the formation of autophagosomes that after packing macromolecules and organelles merge with endosomes and/or lysosomes for content degradation [40]. Multiple forms of cellular stress can induce this pathway that determines cell survival or death [41]. Thereby, autophagy has been described as a cell survival mechanism [38, 42], but it might become an effective way of removing the injured cell from a tissue in case of severe damage. Autophagosomes inside the cytoplasm were noticeable in AZA1-treated cells, indicating an active generation of these double-membrane vesicles to ingest cytoplasmic material. In agreement with our results, it was previously described that some marine toxins can activate autophagy [43]. Therefore the ultrastructural alterations in Caco- 2 cells may be due to an attempt to maintain cell survival by the autophagic mechanism [38] triggered by the AZA1 insult [42].

\section{Conclusion}

The results of this study demonstrated that AZA1 passes through the Caco-2 monolayer without changing cell viability but causing mitochondrial damage and increase of autophagosomes. Accordingly, after the ingestion of molluscs with AZA1, the toxin crosses the human intestinal barrier, passes to blood and reaches any target organ. Even though further investigations are required to clarify the mechanism of action, those data should be taken into account in the evaluation of azaspiracid poisoning in humans.

\section{Acknowledgements}

The research leading to these results has received funding from the following FEDER cofunded-grants. From CDTI and Technological Funds, supported by Ministerio de Economía, Industria y Competitividad, AGL2014-58210-R, AGL2016-78728-R (AEI/FEDER, UE), ISCIII/PI16/01830 and RTC-2016-5507-2. From CDTI under ISIP Programme, Spain, IDI20130304 APTAFOOD and ITC-20161072. From the European Union's Seventh Framework Programme managed by REA - Research Executive Agency (FP7/2007-2013) under grant agreement 312184 PHARMASEA. 


\section{Cellular Physiology Cell Physiol Biochem 2017;43:136-146 \begin{tabular}{l|l} 
DOI: 10.1159/000480331 2017 & $\begin{array}{l}\text { O 2017 The Author(s). Published by S. Karger AG, Basel } \\
\text { www.karger.com/cpb }\end{array}$ \\
\hline and Biochemistry
\end{tabular} \\ Abal et al.: Absorption of Azaspiracid-1}

Disclosure Statement

The authors declare no Disclosure Statement

\section{References}

-1 Jauffrais T, Herrenknecht C, Sechet V, Sibat M, Tillmann U, Krock B, Kilcoyne J, Miles CO, McCarron P, Amzil Z, Hess P: Quantitative analysis of azaspiracids in Azadinium spinosum cultures. Anal Bioanal Chem 2012;403:833-846.

-2 Krock B, Tillmann U, Voss D, Koch BP, Salas R, Witt M, Potvin E, Jeong HJ: New azaspiracids in Amphidomataceae (Dinophyceae). Toxicon 2012;60:830-839.

-3 Krock B, Tillmann U, John U, Cembella A: LC-MS-MS aboard ship: tandem mass spectrometry in the search for phycotoxins and novel toxigenic plankton from the North Sea. Anal Bioanal Chem 2008;392:797-803.

4 Twiner MJ, Rehmann N, Hess P, Doucette GJ: Azaspiracid shellfish poisoning: a review on the chemistry, ecology, and toxicology with an emphasis on human health impacts. Mar Drugs 2008;6:39-72.

5 Aune T, Espenes A, Aasen JA, Quilliam MA, Hess P, Larsen S: Study of possible combined toxic effects of azaspiracid-1 and okadaic acid in mice via the oral route. Toxicon 2012;60:895-906.

6 Ito E, Satake M, Ofuji K, Higashi M, Harigaya K, McMahon T, Yasumoto T: Chronic effects in mice caused by oral administration of sublethal doses of azaspiracid, a new marine toxin isolated from mussels. Toxicon 2002;40:193-203.

7 Satake M, Ofuji K, Naoki H, James KJ, Furey A, McMahon T, Silke J, Yasumoto T: Azaspiracid, a new marine toxin having unique spiro ring assemblies, isolated from Irish mussels, Mytilus edulis. Journal of the American Chemical Society 1998;120:9967-9968.

-8 Ferreiro SF, Vilarino N, Carrera C, Louzao MC, Santamarina G, Cantalapiedra AG, Rodriguez LP, Cifuentes JM, Vieira AC, Nicolaou KC, Frederick MO, Botana LM: In vivo arrhythmogenicity of the marine biotoxin azaspiracid-2 in rats. Arch Toxicol 2014;88:425-434.

-9 Ferreiro SF, Vilarino N, Carrera C, Louzao MC, Cantalapiedra AG, Santamarina G, Cifuentes JM, Vieira AC, Botana LM: Subacute Cardiovascular Toxicity of the Marine Phycotoxin Azaspiracid-1 in Rats. Toxicol Sci 2016;151:104-114.

10 Cao Z, LePage KT, Frederick MO, Nicolaou KC, Murray TF: Involvement of caspase activation in azaspiracidinduced neurotoxicity in neocortical neurons. Toxicol Sci 2010;114:323-334.

11 Roman Y, Alfonso A, Louzao MC, de la Rosa LA, Leira F, Vieites JM, Vieytes MR, Ofuji K, Satake M, Yasumoto T, Botana LM: Azaspiracid-1, a potent, nonapoptotic new phycotoxin with several cell targets. Cell Signal 2002;14:703-716.

-12 Vilarino N, Nicolaou KC, Frederick MO, Cagide E, Ares IR, Louzao MC, Vieytes MR, Botana LM: Cell growth inhibition and actin cytoskeleton disorganization induced by azaspiracid-1 structure-activity studies. Chem Res Toxicol 2006;19:1459-1466.

13 Kellmann R, Schaffner CA, Gronset TA, Satake M, Ziegler M, Fladmark KE: Proteomic response of human neuroblastoma cells to azaspiracid-1. J Proteomics 2009;72:695-707.

$>14$ Twiner MJ, Doucette GJ, Rasky A, Huang XP, Roth BL, Sanguinetti MC: Marine algal toxin azaspiracid is an open-state blocker of hERG potassium channels. Chem Res Toxicol 2012;25:1975-1984.

-15 Ferreiro SF, Vilarino N, Louzao MC, Nicolaou KC, Frederick MO, Botana LM: In vitro chronic effects on hERG channel caused by the marine biotoxin azaspiracid-2. Toxicon 2014;91:69-75.

-16 Chevallier OP, Graham SF, Alonso E, Duffy C, Silke J, Campbell K, Botana LM, Elliott CT: New insights into the causes of human illness due to consumption of azaspiracid contaminated shellfish. Scientific Reports 2015;5:9818.

17 Louzao MC, Espina B, Cagide E, Ares IR, Alfonso A, Vieytes MR, Botana LM: Cytotoxic effect of palytoxin on mussel. Toxicon 2010;56:842-847.

18 Jauffrais T, Marcaillou C, Herrenknecht C, Truquet P, Sechet V, Nicolau E, Tillmann U, Hess P: Azaspiracid accumulation, detoxification and biotransformation in blue mussels (Mytilus edulis) experimentally fed Azadinium spinosum. Toxicon 2012;60:582-595.

19 Botana LM: Seafood and Freshwater Toxins: Pharmacology, Physiology, and Detection, Second Edition, CRC Press2008. 


\section{Cellular Physiology Cell Physiol Biochem 2017;43:136-146 \begin{tabular}{ll|l} 
and Biochemistry Published onlIne: August 28, 2017 & $\begin{array}{l}\text { (c) } 2017 \text { The Author(s). Published by S. Karger AG, Basel } \\
\text { www.karger.com/cpb }\end{array}$
\end{tabular}}

Abal et al.: Absorption of Azaspiracid-1

20 Regulation E: Regulation (EC) No 853/2004 of the European Parliament and of the Council of 29 April 2004 laying down specific hygiene rules for food of animal origin Off. J. Eur. Union 2004;L226:22.

21 U.S. Food and Drug Administration CfDEaRC: Guidance for Industry: Waiver of In vivo Bioavailability and Bioequivalence Studies for Immedate-Release Solid Oral Dosage Forms Based on a Biopharmaceutics Classification System. 2000;

22 Artursson P, Palm K, Luthman K: Caco-2 monolayers in experimental and theoretical predictions of drug transport. Adv Drug Deliv Rev 2001;46:27-43.

23 Lampen A, Bader A, Bestmann T, Winkler M, Witte L, Borlak JT: Catalytic activities, protein- and mRNAexpression of cytochrome P450 isoenzymes in intestinal cell lines. Xenobiotica 1998;28:429-441.

-24 Ebert B, Seidel A, Lampen A: Identification of BCRP as transporter of benzo [a]pyrene conjugates metabolically formed in Caco-2 cells and its induction by Ah-receptor agonists. Carcinogenesis 2005;26:1754-1763.

25 Espina B, Otero P, Louzao MC, Alfonso A, Botana LM: 13-Desmethyl spirolide-c and 13, 19-didesmethyl spirolide-c trans-epithelial permeabilities: human intestinal permeability modelling. Toxicology 2011;287:69-75.

26 Fernandez DA, Louzao MC, Vilarino N, Fraga M, Espina B, Vieytes MR, Botana LM: Evaluation of the intestinal permeability and cytotoxic effects of cylindrospermopsin. Toxicon 2014;91:23-34.

27 Fraga M, Vilariño, N., Louzao M.C., Botana, L.M.: Sensitivity improvement of an immuno-detection method for azaspiracids based on the use of microspheres coupled to a flow-fluorimetry system. Frontiers in Marine Science/IMMR (International Meeting on Marine Research) 2014 2014;10.3389/conf. fmars.2014.02.00166

28 Pinto da Silva P, Kachar B: On tight-junction structure. Cell 1982;28:441-450.

29 Usansky HH, Sinko PJ: Estimating human drug oral absorption kinetics from Caco-2 permeability using an absorption-disposition model: model development and evaluation and derivation of analytical solutions for k(a) and F(a). J Pharmacol Exp Ther 2005;314:391-399.

-30 Hubatsch I, Ragnarsson EG, Artursson P: Determination of drug permeability and prediction of drug absorption in Caco-2 monolayers. Nat Protoc 2007;2:2111-2119.

-31 Twiner MJ, Hanagriff JC, Butler S, Madhkoor AK, Doucette GJ: Induction of apoptosis pathways in several cell lines following exposure to the marine algal toxin azaspiracid. Chem Res Toxicol 2012;25:1493-1501.

32 Hess P, McCarron P, Rehmann N, Kilcoyne J, McMahon T, Ryan G, Ryan MP, Twiner M, Doucette G, Satake M, Ito E, Yasumoto T: Isolation and purification of azaspiracids from naturally contaminated materials, and evaluation of their toxicological effects (ASTOX). Marine Environment and Health Series 2007;28:35.

33 Ferron PJ, Dumazeau K, Beaulieu JF, Le Hegarat L, Fessard V: Combined Effects of Lipophilic Phycotoxins (Okadaic Acid, Azaspiracid-1 and Yessotoxin) on Human Intestinal Cells Models. Toxins (Basel) 2016;8:

-34 Al-Sadi R, Khatib K, Guo S, Ye D, Youssef M, Ma T: Occludin regulates macromolecule flux across the intestinal epithelial tight junction barrier. Am J Physiol Gastrointest Liver Physiol 2011;300:G1054-1064.

-35 Fernandez DA, Louzao MC, Fraga M, Vilarino N, Vieytes MR, Botana LM: Experimental basis for the high oral toxicity of dinophysistoxin 1: a comparative study of DSP. Toxins (Basel) 2014;6:211-228.

-36 Saitou M, Furuse M, Sasaki H, Schulzke JD, Fromm M, Takano H, Noda T, Tsukita S: Complex phenotype of mice lacking occludin, a component of tight junction strands. Mol Biol Cell 2000;11:4131-4142.

-37 Han C, Ding Z, Shi H, Qian W, Hou X, Lin R: The Role of Probiotics in Lipopolysaccharide-Induced Autophagy in Intestinal Epithelial Cells. Cell Physiol Biochem 2016;38:2464-2478.

38 Gomes LC, Di Benedetto G, Scorrano L: During autophagy mitochondria elongate, are spared from degradation and sustain cell viability. Nat Cell Biol 2011;13:589-598.

-39 Han R, Sun Q Wu J, Zheng P, Zhao G: Sodium Butyrate Upregulates miR-203 Expression to Exert AntiProliferation Effect on Colorectal Cancer Cells. Cell Physiol Biochem 2016;39:1919-1929.

40 Furey A, O’Doherty S, O'Callaghan K, Lehane M, James KJ: Azaspiracid poisoning (AZP) toxins in shellfish: toxicological and health considerations. Toxicon 2010;56:173-190.

41 Kroemer G, Marino G, Levine B: Autophagy and the integrated stress response. Mol Cell 2010;40:280-293.

$\checkmark 42$ Thorburn A: Apoptosis and autophagy: regulatory connections between two supposedly different processes. Apoptosis 2008;13:1-9.

43 Korsnes MS, Kolstad H, Kleiveland CR, Korsnes R, Ormen E: Autophagic activity in BC3H1 cells exposed to yessotoxin. Toxicol In vitro 2016;32:166-180. 